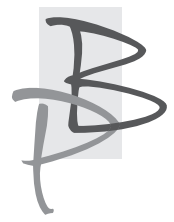

Jarosław Ławski*

Katedra Badań Filologicznych „Wschód - Zachód”

Wydział Filologiczny Uniwersytetu w Białymstoku

https://orcid.org/0000-0002-1167-5041

\title{
Regionalizm na puszczańskich manowcach
}

[Rec. Księga Puszczy Piskiej, pod red. Waldemara Mierzwy, Dąbrówno, Oficyna Wydawnicza „Retman”, 2018; Moja Biblioteka Mazurska nr 30, ss. 413.]

Streszczenie: Artykuł jest krytyczną recenzją tomu Księga Puszczy Piskiej (red. W. Mierzwa, Dąbrówno 2018). Tom ów, zdaniem recenzenta, pozostaje zapisem kryzysu literatury regionalistycznej, którą rządzą przede wszystkim prawa rynku. Troska o poziom edytorski, graficzny nie idzie w parze z troską o jakąkolwiek spójną koncepcję tego typu wydawnictwa. Pokazuje ono atrakcyjny wizualnie, lecz uprzedmiotowiony obraz Puszczy Piskiej, jej przyrody, historii i kultury. Nie zawiera też żadnego programu jej ratowania.

Słowa-klucze: regionalizm, Puszcza Piska, księga, leksykon, Mazury, ochrona przyrody, dziedzictwo kulturowe.

\section{Regionalism in the wilderness astray}

Summary: The article is a critical review of the volume The Book of the Pisz Forest (edited by W. Mierzwa, Dąbrówno 2018). This volume, according to the reviewer, is a record of the crisis of regionalist literature, which is

* Jarosław Ławski - prof. dr hab., kierownik Katedry Badań Filologicznych „Wschód - Zachód" na Wydziale Filologicznym Uniwersytetu w Białymstoku. Autor monografii, m.in. Mickiewicz - Mit - Historia. Studia (Białystok 2010); Miłosz: „Kroniki” istnienia. Sylwy (Białystok 2014). Edytor Horsztyńskiego J. Słowackiego w serii Biblioteki Narodowej oraz III-tomowych Pism rozproszonych Zygmunta Glogera. Członek Komitetu Nauk o Literaturze PAN; członek korespondent Polskiej Akademii Umiejętności. 
primarily governed by market laws. The care for editorial design does not go hand in hand with any coherent concept of this type of publishing. It shows a visually attractive but objectified image of the Pisz Forest, its nature, history and culture. In addition, the volume does not contain any rescue program to save the Forest.

Key words: regionalism, Pisz Forest, book, lexicon, Masuria, nature protection, cultural heritage.

Myśl regionalistyczna była jednym z nurtów refleksji, które zapełniły pustkę po tym, jak refleksja postmodernistyczna osiągnęła apogeum, a potem stopniowo (od 11 września 2001 roku) zaczęła więdnąć, w końcu odeszła w przeszłość jako inspirujący nurt filozoficzny i literacki. Jedną z reakcji na ten fakt był powrót do korzeni, do kategorii „miejsca”, do „geobiografii” umocowanej w konkretnej czasoprzestrzeni historycznej, kulturowej. Najczęściej niedawni jeszcze apologeci ponowoczesności zaczęli ogłaszać programy geopoetyki, postsekularyzmu, geobiografistyki, nowego regionalizmu.

Postmodernistyczny uniwersalista spod znaku wszelkich „post-izmów” już występując jako ,przebrany” regionalista - osiadł w rodzinnym zakątku Śląska, Podlasia, Warszawy, Łodzi, Warmii i Mazur. Ten powrót wydał niejedną znakomitą propozycję teoretyczną, manifest, projekt badań literaturoznawczych, historiograficznych, socjologicznych, by wspomnieć tylko obszernie zakrojony projekt „,noworegionalistyczny” zatytułowany „Nowy regionalizm w badaniach literackich"'. Ruch regionalistyczny szybko wpłynął też na istniejące i nowo powstające ruchy społeczne („Borussia”, „Pogranicze”, „Pogranicza” - już ich nazwy wskazywały na topoi, własne miejsca projektodawców, liderów)². Dość swobodne przejście od postmodernistycznego uniwersalizmu

1 Por. Nowy regionalizm $w$ badaniach literackich. Badawczy rekonesans $i$ zarys perspektyw, red. M. Mikołajczak, E. Rybicka, Kraków 2012; tu: E. Rybicka, Wprowadzenie. Region - rzeczywistość wyobrażona (s. 5-10) oraz Z. Chojnowski, Literaturoznawstwo regionów (w poszukiwaniu skutecznych perspektyw badawczych) (s. 13-28).

2 Niektóre z nich, jak „Borussia”, weszły w fazę schyłku. Por. „Borussia” 60/2017. Na okładce napis: „Uwaga! Ostatni numer Borussii”. 
do regionalizmu dokonywało się przy wsparciu Unii Europejskiej (finansowym), pod hasłami pielęgnowania kultury pogranicza, regionu, multikulturowości.

Rychło jednak ujawiły się i niebezpieczeństwa ruchu regionalistycznego: kulturowo-polityczny separatyzm (casus Krymu i Donbasu, Katalonii, Kraju Basków, Śląska, Zakarpacia i innych) ${ }^{3}$, prowincjonalizacja i instytucjonalizacja ruchu społecznego budowanego za pieniądze grantowe, unijne, wreszcie zatracenie miary pomiędzy wartością tego, co regionalne, a tym, co narodowe (i zarazem uniwersalne) ${ }^{4}$.

Nie miejsce tu, by śledzić losu ruchy regionalistycznego w Polsce. Dość rzec, iż z poziomu teorii, metody szybko zszedł on na poziom województw, regionów, miast, gmin, poszczególnych obiektów. Towarzyszył temu potężniejący z każdym rokiem strumień publikacji poświęconych prowincjom, zabytkom, miastom i wioskom, „miejscowym” ludziom i legendom opowiadanym przez lud. Literatura ta będzie kiedyś przedmiotem szczegółowych badań.

Chciałbym wskazać na jeden jej szczególny przypadek rodem z Warmii i Mazur. To region specyficzny, naznaczony pruską historią, germańsko-słowiańsko-bałtycką i katolicko-protestancką odmiennością. Historycznie to dwa odmienne regiony: Warmia i (osobno) Mazury; do tego dodajmy geopolityczny (nowo)twór Obwodu Kaliningradzkiego, zimnowojenny pomnik imperialnego stalinizmu, „niezatapialny lotniskowiec” Rosji w ciele UE i NATO. Historia w tym miejscu świata na początku XXI wieku rozwija się w groźnym kierunku. Ale nie o polityce tym razem mowa - regionalizm warmińsko-mazurski (lub dwa regionalizmy, jak kto woli) czerpie siłę nie z geopolityki, lecz z historii i przyrody5. To one tworzą niezwykły potencjał turystyczny, gospodarczy, marketingowy tych ziem.

Wydana w 2018 roku pod redakcją Waldemara Mierzwy Księga Puszczy Piskiej („Moja Biblioteka Mazurska” nr 30$)^{6}$ to dzieło imponujące od strony

3 Por. J. Prochaśko, Co może, a co nie może być regionem, „Autoportret. Pismo o Dobrej Przestrzeni" 2(57) 2017, s. 47-52. Numer: Regionalizmy/Modernizmy/Postmodernizmy.

4 Pisałem o tym w: J. Ławski, Przeciw kategorii „,pogranicza”, [w:] Regionalizm literacki-historia i pamięć, red. Z. Chojnowski, E. Rybicka, Kraków 2017.

5 Zob. S. Lenz, Na przykład ja. Znaki szczególne pewnego rocznika (1926), przeł. A. Kopacki, „Borussia” 48/2010, s. 10-25.

6 Chcę podkreślić, że wiele książek wydanych w tej serii to prawdziwie cenne pozycje, źródła, dzieła literackie i naukowe, z których sam korzystam! 
edytorskiej: duży format, piękne zdjęcia, teksty napisane przez dwudziestu autorów związanych z regionem: profesorów, pisarzy, regionalistów. Większość znakomitych zdjęć wykonali profesjonaliści: Mieczysław Wieliczko, Krzysztof Stasiaczek. Ilustracje pochodzą z archiwów muzealnych, bibliotecznych, prywatnych ${ }^{7}$. Na końcu tomu znajdziemy dział Polecane lektury (tu zaczynają się przykre potknięcia ${ }^{8}$. Tom posiada - za co należą się wyrazy uznania edytorom - indeks nazwisk i indeks nazw geograficznych. Rzecz zdaje się redakcyjnie dopracowana w szczegółach. Na końcu pomieszczono noty $O$ autorach tekstów wraz z ich zdjęciami, co jest rzadkie w pracach popularyzatorskich.

Zapiera dech okładka tonąca w odcieniach zieleni: wataha wilków złożona z przynajmniej 12 osobników buszuje po mazurskich polach (gdzie są u nas, na Mazurach, takie watahy wilków? - w Strzałkowie). Piękne, panoramiczne ujęcie obejmuje wszystkie strony okładki, grzbiet książki. Tytuł obiecuje wiele: przede wszystkim ma to być ks ięga, coś znacznie obszerniejszego niż książka i zapewne też jakościowo lepszego, istotniejszego, pretendującego do objęcia zagadnienia $\mathrm{z}$ wszech stron.

„Księgę” otwiera wstęp zatytułowany Na początek. Pisany jest z pozycji swojaka, który drwi z „miastowych” pytających o „puszczę”, podczas gdy, jak wiadomo, na Mazurach wszyscy „miejscowi” żyją po prostu od zawsze „w lesie”. Dziwny to wstęp i nieprzemyślany. Zaczyna się od ironicznego pouczenia czytelnika, by zaraz potem podważyć w ogóle sensowność zainteresowania samą ,puszczą”, bo: „Dziś puszcz, czyli wielkich, niezamieszkałych kompleksów leśnych, już nie ma. Pod tą nazwą kryją się teraz duże obszary, o ukształtowanych przez człowieka drzewostanach, nieużytkowane wcześniej rolniczo" $(K, 5)$. Nie wchodzę w spór o istnienie puszcz (naturalnych, pierwotnych), nie pytam, czy istnieje Puszcza Białowieska, chcę zapytać, po co

7 Wszystkie cytaty z Księgi Puszczy Piskiej (red. W. Mierzwa, Dąbrówno 2018) podaję za tym wydaniem. Cytaty z tomu oznaczam skrótem $K$, po którym podaję nr strony cyfrą arabską. Cytaty lokalizuję w tekście głównym.

8 Wśród grzechów wydawcy ten drobny wydaje mi się (osobiście) przykry. W. Mierzwa korzysta z edycji wspomnień Edwarda Małkka (Gdzie jest moja Ojczyzna? Wspomnienia, Białystok-Ełk, wyd. I: 2016, wyd. II: 2017), nie podając, iż tekst opracował i poprzedził wstępem J. Ławski (czyli niżej podpisany), a drugi wstęp napisał ks. Dariusz Zuber. Tak się nie robi nawet $\mathrm{w}$ pracy popularyzatorskiej. 
ten pseudoparadoks: ma to być Księga Puszczy..., czy księga ukształtowanych przez człowieka drzewostanów? Po co zatem ta puszczańskość w tytule? Bo lepiej brzmi marketingowo? Czy w Puszczy Piskiej, w której się wychowałem, naprawdę oryginalne, puszczańskie jest to, że zajmuje „obszar dwa razy większy od zajmowanego dziś przez Warszawę" (K, 5; frazę tę, jako rzekomo zachęcającą czytelnika, powtórzono w nocie z tyłu okładki).

W sposób niezamierzony autor dookreślił tu potencjalnego czytelnika, czyli człowieka z Warszawy, zwanego na Mazurach „letnikiem”, „warszawiakiem”, „miastowym”. To on ma kupić to piękne edytorsko dzieło - czy jednak jest ono o „Puszczy Piskiej”? I czy to naprawdę „księga”?

Wątpliwości wzrastają z każdym fragmentem wstępu. Czwarty akapit przynosi rys historii regionu, zaczynający się od zdania: „Rok 1945 zapoczątkował nieodwracalną przemianę narodowościowego oblicza ziem całych dawnych Prus Wschodnich, radykalnie zmieniła się oczywiście także sytuacja w Puszczy Piskiej”(K, 5). Czyżby to była taka pierwsza zmiana? APrusowie, Jaćwingowie, których zmiażdżyli Krzyżacy, a wchłonęli, zgermanizowali i sprotestantyzowali niemieccy mieszkańcy tych ziem ${ }^{9}$. Co z nimi? Opis historii zaczyna się tu od „niewyobrażalnej tragedii” niemieckiej roku 1945. A jej przyczyny, nazizm? Owszem, pojawią się, ale w kontekście żydowskim ${ }^{10}$. A rola Prus Wschodnich w 1939 roku, z których to ziem ruszyły ataki na Polskę? Postawy ich mieszkańców? Mierzwa przedstawia w jednym rzucie historię Prus Wschodnich (Warmii i Mazur) jako ciąg migracji: Niemców zastępują Polacy, Ukraińcy, staroobrzędowcy. Niemcy wypierają i mordują Żydów; Mazurzy uciekają do Niemiec. A Polacy? Co z Mazurami, którzy tu jednak, choć nieliczni, pozostali, tworząc także polską kulturę? Co z tymi, którzy po wojnie tu się urodzili? Załóżmy, że stanowią oni wszyscy nieinteresujący dla turysty wyjątek. Co zatem z Polakami, którzy tu mieszkają: „Dla tysięcy dzisiejszych mieszkańców Puszcza jest miejscem do życia i źródłem utrzymania, dla ludzi zamieszkujących wielkie miasta jedynie celem wakacyjnych wyjazdów. Tutejsze jelenie od wieków cieszyły się zainteresowaniem wszelkiej maści myśliwych, (...)" $(\mathrm{K}, 6)$. Po jeleniach autor wymieni: „(...) dość [sic! - J. Ł.] liczną grupę

9 Por. M. Okulicz-Kozaryn, Dzieje Prusów, Wrocław 1997.

10 Zob. jedno z najciekawszych haseł Księgi... zatytułowane: Puszczańscy Żydzi R. W. Pawlickiego (s. 235-239). 
ludzi kultury” i „ludzi aktywnych i kreatywnych”: „Wielu z nich mieszka tu od lat, większość została ju ż naw et [podkr. moje - J. Ł.] zaakceptowana przez sąsiadów, niektórych znajdziecie na łamach tej Księgi" (K, 6). Pomijam honorowe pierwszeństwo jeleni przed ludźmi - miałoby ono nawet jakieś szlachetne uzasadnienie, gdyby owa „Księga” „Puszczy Piskiej” była hymnem na część przyrody, wołaniem o jej ochronę lub szlachetnym głosem o utworzeniu Mazurskiego Parku Narodowego. Płonne nadzieje. Księga ... i wprowadzający do niej wstęp w ogóle nie napomykają o ochronie przyrody jako postulacie redakcji, celu tegoż wydawnictwa.

Zza słów wstępu przebija prowincjonalny kompleks gorszości: tu, z dala od mitycznych „wielkich” miast wszystko jest gorsze. Ludzie uciekli, wsie i miasteczka opustoszały, chyba tylko myśliwi są ostatnią nadzieją lasu. I drwale. Równie osobliwe jest zakończenie zatytułowane Na koniec, gdyż i tu powraca topika kompleksu drugorzędności. „Puszcza Piska przyciąga każdego dnia dziesiątki tysięcy turystów" - pisze redaktor. Ilu konkretnie? Nie wiadomo. Ale pewne, że tu, w Puszczy, nie da się żyć:

„Chyba wszyscy wyjeżdżają stąd zauroczeni jej pięknem, część wraca, by kupić tu lub samemu wznieść dom. To, co fascynuje w Puszczy mieszkańców dużych miast, dla tych, którzy tu mieszkają w niej na co dzień bywa poważnym problemem. Z ciszy leśnej głuszy żyć bowiem potrafią doprawdy jedynie nieliczni, wszyscy pozostali potrzebują miejsc pracy.

Po 1989 roku Puszcza zaczęła się wyludniać, emigracja zarobkowa przybrała ogromne rozmiary, nie ma nadziei, aby w najbliższym czasie udało się ten proces powstrzymać. Pustoszeją miasta, zamierają wioski, las zaczyna odzyskiwać odebraną mu niegdyś ziemię. Czyżby historia zaczęła zataczać swe koło?" (K, 355).

Czyżby najlepsze czasy już kiedyś były? Kiedy? W PRL-u. Tak, wtedy puszcza żyła - letnikami z FWP i partyjnymi myśliwymi. Ten obraz jest przerażający. Czyż autor Księgi... zapomniał biedę tamtych lat? Nie widział, jak zmieniły się puszczańskie osady i miasteczka po '89 roku? Sam sobie przecząc, autor podsumowania pt. Na koniec przywołuje na finał cytat z Dzieci Jerominów Wiecherta, pokazujący, że w nowoczesnym świecie wyjeżdżanie z Puszczy, z puszcz, to proces stały, już dwóchsetletni: „Niejeden wykradał się o zmroku ku dzikiej gruszy rosnącej na miedzy, gdzie pogrzebane było jego dzieciństwo i przypatrywał się w przygnębieniu i ponurej żałobie owej ubogiej krainie, która i jemu była 
obiecana, a którą opuścił dla miski soczewicy"11. Po co jednak mieliby wracać do Puszczy na stałe absolwenci uniwersytetów, właściciele firm, artyści - ci, którzy tu się rodzili, wzrastali? Spróbujmy odpowiedzieć na to pytanie.

Pierwsze przypuszczenie każe zawołać: przyjadą tu ze swoimi dziećmi, by pokazać im piękno przyrody. Na stronach przedtytułowych i tytułowych orły oraz piękny ryś schodzący z drzewa ${ }^{12}$. Wiele to obiecuje. Ale pierwsze strony książki kończą tę iluzję. Tom zbudowany został z kilkudziesięciu haseł napisanych a to przez zamieszkałych tu „gości”, a to „tutejszych” regionalistów ${ }^{13}$. W zdecydowanej większości przynoszą one mnóstwo pożytecznych informacji. Przywołam kilka takich haseł ludzi głęboko Mazurom, ich przyrodzie oddanym: Puszcza w literaturze (Zbigniew Chojnowski), Mate, wielkie Kadzidtowo (Krzysztof A. Worobiec), Moja Biała Piska (Mirosława Pałaszewska), Świat ptaków (Marian Szymkiewicz).

Jednak do samej Puszczy i Księgi... prowadzą inni bohaterowie: na przykład Ludwik Śliwka, leśnik, nadleśniczy, który wyznaje (on, urodzony w 1930 roku, zaprezentowany na tle „słynnego myśliwskiego gabinetu”, w tle którego poroża i czaszki dziesiątek zwierząt): „Do dzisiaj nic się nie zmieniło i Puszcza nadal sosną stoi. Tyle, że wycinają tak cienkie, czyli młode drzewa, że nie sposób tego zrozumieć!” (K, 11). Potem jest wyznanie Mieczysława Wołonkiewicza (ur. 1942), robotnika leśnego: „Za dużo dzisiaj bierzemy masy z Puszczy w wieku, w którym drzewo powinno jeszcze dorastać" (K, 12). Tak Księga ... odsłania w sposób niezamierzony dramat współczesnej Puszczy: rabunkową gospodarkę, wycinki, polowania, kłusownictwo pod hasłami „gospodarki leśnej i rybackiej”. Te zjawiska potępia w haśle Klusownictwo Dietmar Serafin (skądinąd myśliwy).

11 Niestety, znów ani po cytacie, ani w części Polecana literatura nie podano jednego z autorów - czyli thumacza dzieła. Zob. E. Wiechert, Dzieci Jerominów, przeł. T. Ostojski, J. Ptaszyński, Olsztyn 1973.

12 Chcielibyśmy się dowiedzieć: gdzie na Mazurach został sfotografowany ten piękny osobnik?

13 Ich autorami są: Zbigniew Chojnowski, Bartosz Dziewanowski-Stefańczyk, Katarzyna Enerlich, Mirosław Gworek, Marek Kaczmarczyk, Robert Kempa, Dominik Krysiak, Janusz Małłek, Krzysztof Marusiński, Waldemar Mierzwa, Kazimierz Orłoś, Mirosława Pałaszewska, Ryszard Wojciech Pawlicki (współpraca redakcyjna), Dietmar Serafin, Daria Sikorska, Piotr Sikorski, Łukasz Szymański, Marian Szymkiewicz, Krzysztof A. Worobiec i Tekla Żurkowska. Zdecydowanie najwięcej haseł napisali: W. Mierzwa (10), D. Serafin (10), R. W. Kempa (6), M. Gworek (11), K. A. Worobiec (10). 
Kolejne jednak hasło tego samego autora budzi wątpliwości: Jeleń. Król Puszczy. Jest to spojrzenie myśliwego, pisane nieznośną dla współczesnego człowieka nowomową: oto „redukcja jelenia” oznacza jego masowy odstrzał. „W ślad za redukcją jeleni, wbrew zasadom, nastąpiło stopniowe pogarszanie jakości poroży, wynik bezkarnego strzelania do >wszystkiego, co się rusza $<"$ $(\mathrm{K}, 25)$. Tę opowieść łowcy krasi anegdotka Ludwika Śliwki Kulik. Byk premiera $(\mathrm{K}, 25-26)$. Clou hasła - pokazującym „ideologię” Księgi... - jest przepis kucharski: na lewej stronie zdjęcie ryczącego jelenia, zaś na prawej wyodrębniony graficzne przepis na Pulpety z jelenia w sosie musztardowym $(\mathrm{K}, 23)$. Osobiście odbieram takie traktowanie przyrody jako przerażające, rozmijające się z duchem czasów i wrażliwością ludzi XXI wieku. Komu mało, znajdzie tu nadto przepis na Roladę z dzika (przelatka). Jak wyjaśnia wydawca, przelatek jest to „dzik w drugim roku życia o wadze $35-70 \mathrm{~kg}$ ” (K, 289). Znów jest to hasło napisane przez myśliwego: Czarny zwierz, czyli dzik (tamże).

Do najgorszych stron tomu należą te zawierające zdjęcia, które pokazują tryumfalizm myśliwych; Serafin prezentuje się w okolicznościach łowieckiego tryumfu: „Dietmar Serafin ze swoim największym odyńcem o wadze 145 kg” (K, 288). Nieco dalej: „Ludwik Śliwka na polowaniu. Lata osiemdziesiąte ubiegłego wieku" (K, 291). Jeśli piszą tu o wilkach, to jako pladze lat powojennych: oto „Trofea >akcji wilczej<” $(\mathrm{K}, 292)^{14}$.

Zdjęcie, które w książce w ogóle nie powinno być zamieszczone, pojawia się w haśle Koło Łowieckie „Zielony Krag ” Serafina. Przedstawia „Dietmara Serafina z synem Łukaszem przy ustrzelonym wilku. Styczeń 1985 roku" (K, 131). Około 10-letni chłopiec stoi z zasępioną twarzą nad ciałem martwego wilka z otwartym pyskiem. To zdjęcie-symbol. Pokazuje ideologię myśliwych, którzy tę księgę w dużej części pisali: przyroda ma się podporządkować gatunkowi panującemu, ludziom, ci mogą z nią robić, co zechcą. W latach 80 . ubiegłego wieku, kiedy wykonano to makabryczne zdjęcie, wilków w Puszczy niemal już nie było. Wtedy tam mieszkałem.

Nie tylko wilków nie było. Horrendum stanowią dwa hasła poświęcone rysiowi. Przecież po ostatniej akcji ratowania gatunku z lat 2004-2012 żyje

14 Gwoli wyjaśnienia: nikt nie wzbrania myśliwym publikowania nawet najbardziej przerażających zdjęć ich łowieckich „tryumfów” w środowiskowych pismach, albumach. Ale jednak książka dla masowego odbiorcy jest czymś innym. 
ich, rysiów, tylko kilka w Puszczy. Dlaczego wyginęły? Niezawodny mistrz myślistwa znów i bez zażenowania zdradza tajemnicę - tym razem zagłady rysia w latach 80 . XX stulecia:

„(...) Ponieważ rysie już się wtedy [koniec lat 70.] rozpleniły i stały się zwierzyną łowną, widząc desperację profesora, wypisałem mu odstrzał, a ten następnego dnia zaprezentował mi strzelonego osobnika. Nawiasem mówiąc, był to pierwszy ryś strzelony po II wojnie światowej w Puszczy Piskiej. Gratulacjom nie było końca!

W następnych latach strzelono tu i ówdzie kilka rysi, a pewnej niedzieli, na początku tal osiemdziesiątych, na polowaniu koło Karwicy, padły trzy rysie, czym zakończyła się egzystencja tego pięknego zwierzęcia w piskiej kniei. Wprawdzie natrafiano w późniejszych latach na ślady jego bytności, ale populacja już się nie odrodziła.

Obecnie, dzięki wielkiemu zaangażowaniu doktora Andrzeja Krzywińskiego oraz leśników nadleśnictw Pisz i Maskulińskie, czynione są próby restytucji populacji rysia metodą born to be free. Mimo niewątpliwych osiągnięć, jestem jednak sceptykiem, by metoda ta miała odrodzić rysia w Puszczy" (K, 298).

Tę sama historię zagłady gatunku w Puszczy opowiada kilka stron dalej Marian Szymkiewicz w haśle Trudny powrót rysia. Jest to świadectwo aktu przestępczego:

„Najgłośniejszy i najsmutniejszy przypadek miał miejsce w czasie polowania w okolicy Karwicy w styczniu 1989 roku, gdy wbrew ustaleniom i przepisom odstrzelono ostatnią grupę rodzinną, tj. kotkę i jej dwoje prawie dorosłych młodych. Obserwowano wprawdzie później pojedyncze tropy, ale były to najprawdopodobniej samotne, wędrujące samce, które docierały z Puszczy Augustowskiej. Kłusownictwo oraz nadmierny odstrzał spowodowały, że wystarczyło niecałe dwadzieścia lat, aby populacja rysia w Puszczy Piskiej została całkowicie wyniszczona" $(\mathrm{K}, 300)$.

Można zapytać, jakie jest stanowisko Redaktora? Dlaczego drukuje świadectwa przerażającej bezmyślności, braku jakiejkolwiek wrażliwości na przyrodę? Co w nich >romantycznego $<$ ? A może chodzi o utrwalenie świadectw historycznych? No nie, to nie jest książka historyczna. Księga ... nie ma literalnie żadnej wymowy: nie jest ani głosem w sprawie ochrony Puszczy, ani przeciw niej. To zlepek ciekawostek, których jeden biegun wyznacza przepis na pasztet z ,przelatka”, a drugi poczciwe, rzetelne hasło Świat zwierząt mniejszych. Ide- 
ologia, pseudomitologia gospodarki leśnej, myślistwa, rybactwa miesza się tu z prowincjonalnym kompleksem końca świata, który najlepsze lata przeżywał w PRL-u. Wtedy - po wojnie - odbyła się >piękna< ,akcja wilcza”, wtedy naganiano tu premierom i kacykom jelenie, dziki; wtedy mordowano ostatnie rysie i wilki, bo po prostu w tym państwie klasa wybrana i jej część, prawdziwi i udawani myśliwi, mogli robić wszystko.

Powiedzmy jednak, by obraz nie był jednostronny, że Księgę ... ratują głosy, które wymknęły się redakcji, głosy ludzi zapytanych o zdanie. Ci chórem mówią jedno: las jest niszczony, puszcza cięta bez opamiętania, ochronę przyrody ma się w pogardzie: [Adam Witkiewicz]: „W Puszczy jest miejsce na park narodowy, niby Mazury są >zielonymi płucami<, a nie mają żadnego parku" (K, 92); „Największą cenę za ten tłok [turystów w Krutyni - J. Ł.] płaci przyroda (...), niezadługo nie będzie tu po co przyjeżdżać. Sama przyroda sobie nie poradzi” [Ryszard Kuprajtys; K, 88].

Zastanawiam się, co o Puszczy chcieli przekazać redaktor i autorzy Księgi? Zamiast „księgi” powstał intelektualny gulasz; zamiast silva rerum nieznośny, schizofreniczny tekst o pięknej przyrodzie „puszczy”, której nie ma (bo nie jest puszczą) i w której można wszystko: ciąć, strzelać, niszczyć. Wszystko i tak skończy się roladą z dzika, którą mityczny „warszawiak” zje w drogiej restauracji w drodze do Muzeum w Praniu, placówki, która, jak przekonują w tomie, szerzy wytworzony mit Gałczyńskiego. Czy Księga ... tworzy model literatury regionalnej? O regionie?

Częścią ułożonej w hasła narracji jest literatura piękna i wspomnieniowa, wykorzystywana tu dość obficie. Teksty Ernsta Wiecherta, Igora Newerlego, Romana Bratnego, Edwarda Małłka, Małgorzaty Szejnert, Karola Małłka, Krystyny Sienkiewicz, Andrzeja Strumiłły, Kazimierza Dziewanowskiego, głównie ich wspomnienia, stanowią przerywniki haseł ${ }^{15}$. Niewiele - prócz domów mieszkających tu licznie nie tylko w Krzyżach pisarzy, artystów, dziennikarzy - jest w Puszczy placówek literackich. Jedną z nich jest Muzeum K. I. Gałczyńskiego w Praniu. Hasło Waldemara Mierzwy Pranie. Mit Gałczyńskiego narzuca już profil interpretacji, bo Gałczyński w Praniu to... mit (?). A może muzealne Pranie kultywuje, buduje mit Gałczyńskiego w Praniu? Mierzwa jest

15 Na przykład hasło Moje Ruciane-Nida Marka Kaczmarczyka zostało wzbogacone wspomnieniem Andrzeja Strumiłly Cmentarz w Rucianem. 
bezlitosny, podkreślając, iż Gałczyński był tu ledwie 12 miesięcy. Odczytajmy dłuższy fragment dywagacji:

„Pisał tu dużo, ale prawie nic o Mazurach. Gdyby Fedecki był wówczas oczarowany Bieszczadami, mielibyśmy dziś do czynienia z bieszczadzkim mitem poety. Mamy z mazurskim. Trochę dętym, przyniesionym z Warszawy, tak często powtarzanym, że w końcu większość nas w ten mit uwierzyła. A przecież nie powinna, bo to nie mieszkańcy Mazur wzięli Gałczyńskiego za $>$ swego $<$ poetę, lecz został on Mazurom niejako przypisany.

Nieznajdujący udokumentowania w twórczości poety, mazurski mit Gałczyńskiego ukształtowały działania wielu osób, m.in. Jerzego Putramenta, Andrzeja Drawicza i córki poety, wsparte przez peerelowskie władze centralne i działaczy, a także ludzi kultury szczebla wojewódzkiego. Mit ten opiera się na wielu fantasmagoriach, ale i co najmniej jednym fundamentalnym kłamstwie, jakoby poeta wyjechał na Mazury zrozpaczony zakazem druku wydanym przez władze w czerwcu 1950 roku, co miało być konsekwencją socrealistycznego ataku Adama Ważyka na poetę podczas V Zjazdu Związku Literatów Polskich (...)" $(\mathrm{K}, 211)$.

Już na kolejnej stronie autor zdradza, z jakich źródeł zaczerpnął tę interpretację ${ }^{16}$. Jakież to wszystko proste! - Poeta, wynika z tego, żeby być zaakceptowany, musi poznać region, żyć w nim latami, musi być wygnany, mieć tu schronienie. Tego typu podejście wydaje się kuriozalne. Poeci nie jeżdżą po kraju, by fundować miejsca, gdzie powstaną później ich muzea. Poezja jest kwestią wyobraźni i duchowości, które formują tekst w konfrontacji z obrazami, ze zmysłowym obrazem świata. Każdy pobyt, nawet tygodniowy, nieprzeciętnego człowieka o ile znajduje odzwierciedlenie kulturowe - jest wydarzeniem: i dla miejsca, i dla ludzi w nim skupionych, a w końcu dla pisarza. Ileż u Gałczyńskiego Mazur! W krajobrazie, w ontologii słowa. Cóż to znaczy, że „,...) żaden z tych [napisanych w Praniu - J. Ł.] utworów nie jest mazurski, najbliższa geograficznie, dzięki tytułowi (choć sam Olsztyn leży na Warmii), jest oczywiście Kronika, ale i tak za mazurską może być uznana właściwie jedynie dlatego, że na Mazurach

16 Z. Chojnowski, Od biografii do recepcji. Ernst Wiechert, Konstanty I. Gałczyński, Zbigniew Herbert na Warmii i Mazurach, Olsztyn 2011 oraz A. Drawicz, Gałczyński na Mazurach, Warszawa 1971.

- Żadna z tych książek nie trafiła do literatury polecanej. Cytatów $(K, 217)$ nie oznaczono stronami. Tak też nie wolno czynić. 
została napisana" (K, 211-212). A mówimy tu o takich klasycznych tekstach literatury polskiej, jak Niobe, Wit Stwosz, Kronika olsztyńska, Pieśni, Chryzostoma Bulwiecia podróż do Ciemnogrodu! I to mało, że powstały w Praniu?

Światło na to malkontenctwo autora rzuca inne hasło: Wizyty słynnych myśliwych autorstwa Ryszarda W. Pawlickiego. Tak, w tym przypadku wystarczyło kilka dni zabijania zwierząt przez „sławnych”, by Puszczę naznaczyć światłością Johna Steinbecka lub hiszpańskiego króla Juana Carlosa I. Znów: kompleks prowincji wyziera zza każdego passusu tej Księgi...

Poruszył mnie opis Muzeum Gałczyńskiego, które znam od przełomu lat 80. i 90. ubiegłego wieku' ${ }^{17}$. Widziałem je i opisałem w latach 90. zeszłego stulecia - panowały tam zgrzebność i siermięga. Dziś jest to zadbane w każdym calu, żywe, głośne w całym kraju Muzeum. Ośrodek, gdzie promuje się kulturę i ją tworzy. To zasługa Jagienki i Wojciecha Kassów, od dwudziestu lat dbających o to miejsce. Użyczyli oni redaktorom Księgi... zdjęć z domowego archiwum. Oto jak ich wysiłki podsumował redaktor Mierzwa:

„Następcą Gałczyńskiej na stanowisku kustosza został sopocki poeta, czy też raczej poeta z Sopotu, Wojciech Kass. Nie podjął on walki z mazurskim mitem Gałczyńskiego, słusznie zakładając, że zakończyłaby ona żywot muzeum. Przedsięwziął za to, z żoną Jagienką, naprawdę udane staranie celem zwrócenia uwagi na poezję i poetów w ogóle. Letnie imprezy artystyczne z udziałem wybitnych aktorów i muzyków ściągają licznych wielbicieli pięknego słowa i dobrej muzyki. O ważne laury ubiegają się tu poeci. Dla nich prańska leśniczówka stała się miejscem pielgrzymowania, a sama już tylko znajomość z kustoszem powodem do nie tylko środowiskowej dumy. Nie zmienia to faktu, że systematycznie spada liczba gości odwiedzających muzeum. Dorastają kolejne pokolenia, którym nazwisko Gałczyńskiego nie mówi nic lub prawie nic. Bohdan Czeszko zauważył w Nostalgiach mazurskich, że >rychło umiera pisarz wraz z tym, co wymyślił i zapisał (...). Ostają się geniusz albo dziwacy<.

Gałczyński wielkim poetą był. Okazuje się, że to może być za mało" (K, 214).

Każdy, kto bodaj zetknął się z Gałczyńskim - poetą i jego tekstami, z Muzeum w Leśniczówce Pranie, zaprzeczy tej czarnej legendzie. Znów: wszyst-

17 Por. też: J. Ławski, Wielkie improwizacje nad Jeziorem Krzywym, „Gazeta Współczesna" 1999. 
ko, co dobre - zdaniem Mierzwy - już było, minęło. Ale kiedy było to „dobre”, jeśli nie było go w czasach Gałczyńskiego, który pisał tu klasyczne, ale nie „mazurskie” teksty, jeśli nie było go potem, kiedy tworzono fałszywy mit poety z Mazur? O co chodzi w tym haśle? Mierzwa pisze: „Byłem w muzeum w Praniu w 1988 roku. Zrobiło na mnie fatalne wrażenie" (K. 214). Mniej więcej $\mathrm{w}$ tym samym czasie byłem tam i ja pierwszy raz i też odniosłem to wrażenie. Lecz nie była to opinia o Gałczyńskim, lecz o stanie Muzeum: zapuszczonego, prowincjonalnego. Czy autor hasła był tam teraz? Po co narzuca nam przekonanie, że wszystko ginie, umiera, że wszystko tu, w Puszczy, jest klęską? Jego podrabianie Gombrowicza nie zdradza ironisty, raczej zgorzkniałego melancholika, który nie wierzy nie tylko w przyszłość, ale i teraźniejszość. Gałczyński był znakomitym poetą, jest klasykiem. I ma wspaniałe Muzeum w Praniu. Wbrew temu, do czego przekonuje Waldemar Mierzwa.

O potężnej „księdze” można pisać długo. Jej lektura, choć często zajmująca (głównie tam, gdzie opowiada o konkretnych miejscowościach), przynosi ogromne rozczarowanie. By rzecz jakąś nazwać „księgą”, nie wystarczą gruby papier, kolorowe zdjęcia i teksty. Potrzebna jest koncepcja, idea. Tej tutaj zabrakło, nawet nie podjęto próby jej sformułowania. Dlaczego? Odpowiedź wpisana jest $\mathrm{w}$ model odbiorcy tomu. Wyraźnie widać, że jest nim turysta z „wielkiego miasta” Warszawy, którego przyciągną szata edytorska, zdjęcia, a niekoniecznie historia Spychowa czy Szerokiego Boru. Dla takiego odbiorcy ważny tak samo jak tekst o ratowaniu rysia jest przepis na pasztet z dzika. Jelenie są dlań - na pewno! - bardziej intrygujące niż ludzie. Prusowie czy Jaćwingowie pojawią się tylko wtedy, kiedy staną się częścią puszczańskiego przemysłu turystycznego.

Co wydaje mi się w „księdze” przerażające, to instrumentalny i w gruncie rzeczy obojętny stosunek do przyrody i dóbr kultury. Są one rezerwuarem anegdot: myśliwskich, literacko-myśliwskich, literackich. Jako potencjalnego odbiorcę tego produktu pomyślano też Lasy Państwowe, skąd gładkie hasło „Lasy Mazurskie”. Leśny Kompleks Promocyjny: „Oferta jest naprawdę bogata, każdy, także przyjezdny, znajdzie tu coś dla siebie” (W. Mierzwa; K, 353). Naprawdę? Pod warunkiem, oczywiście, że ominie skłamane mitem poety Pranie.

Należałoby zapytać, jaki gatunek piśmiennictwa użytkowego reprezentuje Ksiega...? Nie jest to album, przewodnik, monografia. Nie nazwano jej słownikiem, encyklopedią, monografią. Na wyrost nazwano „księgą”; cokolwiek rozu- 
mieć przez to słowo, nie jest to księga. Księga ... okazuje się genologiczną hybrydą słownika, leksykonu, folderu, albumu, inkrustowaną wywiadami i cytatami ze wspomnień. To gatunkowa składanka, którą kiedyś trzeba będzie nazwać.

Właściwą ideą „księgi” okazuje się obrót handlowy. To produkt regionalistyczny o wyraźnym ukierunkowaniu merkantylnym. Nie ma nic w tym złego - jeśli tego typu praca ma wymowę. Czy pokazywanie dzieciom warszawskich turystów zdjęć upolowanych, zakrwawionych, martwych wilków, dzików, opowiadanie o zbrodni wybicia ostatnich rysiów tę rolę spełnia? Uczy? Niczego nie uczy. Puszcza Piska, jaką poznaje czytelnik, to miejsce ponure, biedne, godne opuszczenia. Aż strach pomyśleć, że żyło tu tylu artystów, pisarzy, polityków. Jest to miejsce, z którego wszystkie tu egzystujące ludy przepędzały się wzajemnie, często dopuszczając się mordów. Zresztą bestialstwa, wojny, wojsko - to wszystko zostało pomieszczone w głębokim tle i podane w wersji soft, zeufemizowanej, tak jak historia zagłady puszczańskich Żydów. Nie wiadomo też, kto mieszkał tu przed Krzyżakami? Kto mieszka za granicą Obwodu Kaliningradzkiego dziś? Literaturę też wykorzystano instrumentalnie (unikając poezji) ${ }^{18}$.

Obraz świata w Księdze Puszczy Piskiej jest - w pewnej części - obrazem dzisiejszej regionalistyki na jej poziomie użytkowym: scala go z niedobranych fragmentów cel merkantylny. Teoria nowego regionalizmu (regionalności) przełożona na realia przynosi czasem takie dzieła, jak owa „księga”: fascynujące we fragmentach, lecz rozbite, niemal schizofreniczne. Doktor Jekyll notuje tutaj mord na ostatnich wilkach i rysiach, a Mr Hyde opisuje ich współczesne ratowanie (w które pierwszy nie wierzy). Piękna ma być bowiem sama „księga”, czyli ta a nie inna książka do kupienia za „80 zł”, natomiast Puszcza... Cóż, z Puszczy Piskiej warto uciec. Jak Marcin Polewaczyk, rocznik 1980, który dopiero w Southhampton poczuł się dobrze: „Zauważyłem, że jestem spokojniejszy i bardziej wyluzowany. Siostra polubiła życie w Anglii i chce zostać na stałe. My o powrocie na razie nie myślimy. Do Polski, do naszej Puszczy, przyjeżdżamy tylko na urlopy" $(\mathrm{K}, 350)$.

Lecz „to” zjawisko - czyli wyjazdy - też jest normalne, ponieważ zmienił się świat. Nie każdy wyjazd oznacza klęskę, nie każdy powrót jest na zawsze. Puszcza wciąż jest „nasza”.

18 Zapewne dlatego, że poezji tej nie chciałby, jak zakładano, poznawać odbiorca z ,wielkiego miasta" Warszawy. 
Księga... nie mówi ani słowa o tym, że trzeba chronić Puszczę Piską i kto ma to robić. Jest w tomie wiele fascynujących, dobrze, żarliwie napisanych opowieści o konkretnych miejscach. Jest też jednak i nostalgia za PRL-em, za „wielkim” światem polujących notabli.

Zraża obojętność wobec przyrody. Nie dziwię się, że nie znalazłem tu hasła o tyle lat już trwającym n i e p o w o ły w a n i u Mazurskiego Parku Narodowego. Zdumiewam się natomiast, czytając o atmosferze dekadencji w prańskim Muzeum Gałczyńskiego. Pięknie wydany, choć bez korekty interpunkcyjnej, bałagan intelektualny Księgi Puszczy Piskiej da się zrozumieć tylko przyjmując, iż wbrew tytułowi nie jest to żadna „księga”, ale książka dla turystów z Warszawy, którzy przecież, cokolwiek by zawierała, kupią ją i zabiorą do swego „szczęśliwszego” świata.

Szkoda, bo przecież widać w tym tomie jakieś ambicje. Niepodjęte, ambicje nieujęte w słowa, stracone.

\section{Bibliografia}

Białuński G., Kolonizacja "Wielkiej Puszczy” (do 1568 roku) - starostwa piskie, ełckie, straduńskie, zelkowskie i węgoborskie (węgorzewskie), Olsztyn 2002.

Chojnowski Z., Od biografii do recepcji: Ernst Wiechert, Konstanty I. Gałczyński, Zbigniew Herbert na Warmii i Mazurach, Olsztyn 2011.

Kass W., Promienność Prania; Z Wojciechem Kassem, poetą, kustoszem Muzeum Konstantego Ildefonsa Gałczyńskiego w Praniu, rozmawia pisarz Jan Jastrzębski z Gołdapi, „Borussia” 60/2017.

Księga Puszczy Piskiej, red. Waldemar Mierzwa, Dąbrówno 2018.

Małłek E., Gdzie jest moja Ojczyzna? Wspomnienia, opr., red. i wstęp Jarosław Ławski, przedsłowie ks. Dariusz Zuber, Białystok-Ełk 2016. 